\title{
Has the grand idea of geoengineering as Plan B run out of steam?
}

\author{
Anders Hansson and Jonas Anshelm
}

Linköping University Post Print

Tweet

N.B.: When citing this work, cite the original article.

Original Publication:

Anders Hansson and Jonas Anshelm, Has the grand idea of geoengineering as Plan B run out of steam?, 2015, The Anthropocene Review, 1-11.

http://dx.doi.org/10.1177/2053019615614592

Copyright: The Authors.

http://anr.sagepub.com/

Postprint available at: Linköping University Electronic Press

http://urn.kb.se/resolve?urn=urn:nbn:se:liu:diva-122389 


\title{
Has the grand idea of geoengineering as Plan B run out of steam?
}

\author{
Jonas Anshelm and Anders Hansson ${ }^{1}$
}

\begin{abstract}
Paul Crutzen's 2006 call for geoengineering research triggered public debate in the mass media of several countries. Since then, a common belief among numerous involved scientists has been that more geoengineering experimentation or research is needed and that geoengineering should be carefully considered in a precautionary way as an emergency option or 'Plan B'. Despite the controversial potential of geoengineering in terms of mega-risks, ethical dilemmas and governance challenges, public geoengineering debate in the daily press from 2006 to 2013 was heavily dominated by accounts of scientists' arguments for more geoengineering research or even deployment, only about $8 \%$ of mass media articles expressing criticism of geoengineering. However, based on a reading of 700 articles published worldwide in 2014 and 2015, we demonstrate a gradual shift in the coverage, and the daily press now primarily reports critical views of geoengineering technologies. The patterns outlined here point in the same direction: It seems as though the grand idea of geoengineering as Plan B is fading.
\end{abstract}

Keywords

climate change, climate engineering, discourse analysis, geoengineering, mass media, public debate

\section{Introduction}

In this paper we discuss recent changes in how geoengineering (or climate engineering) is portrayed in the mass media and how these changes can be understood. First, we describe how geoengineering was portrayed up to 2014. We continue by illustrating the gradual but significant move towards more modest and critical descriptions of geoengineering as a climate control measure, away from emergency framings and notions of geoengineering as 'Plan B', and instead towards lowered expectations and ambiguity of the very notion of geoengineering. We claim that there has been considerable drift in this direction, strongly illustrated by the public's as well as climate scientists' reception of the 2015 Climate Intervention reports (National Research Council, 2015a, 2015b), as compared with the reception of and declarations concerning the release of the Royal Society’s (Shepherd et al., 2009) study.

In contrast to our argument, Horton (2015) claims that framing geoengineering as a response to a climate emergency still dominates the popular science and mainstream media. This claim merits investigation because, as Horton (2015) maintains, that framing is possibly both unwise and unwarranted because it invokes authoritarian political tendencies and has a weak scientific basis (see also Sillmann et al., 2015).

Our argument is empirically supported by a discourse analysis of public debate on geoengineering in the daily press in 2014 and end of March 2015. We used the Retriever database, which covers 12,000 newspapers globally, and applied the search strings 'climate engineering' and 'geoengineering AND climate'. A total of 700 articles published between 1 January 2014 and 31 March 2015 in English, German, Swedish, Danish and Norwegian were analysed and a limited, not exhaustive, sample of these articles was chosen to illustrate the analysis.1

\section{Geoengineering in the mass media before 2014}

In response to slow progress in international climate negotiations and the ongoing increase in greenhouse gas (GHG) emissions, geoengineering has received considerable attention from scientists and journalists, frequently

\footnotetext{
${ }^{1}$ Corresponding author:

Anders Hansson, Department of Thematic Studies,

Technology and Social Change, Linköping University,

SE-581 83 Linköping, Sweden.

Email: anders.n.hansson@liu.se
} 
being described as having great potential or as a necessary emergency option if climate tipping points are crossed leading to abrupt, nonlinear and irreversible climate change, or as 'Plan B' as an alternative if mitigation fails (e.g. Harnisch et al, 2015; Horton 2015; Huttunen et al 2014; Loukkanen et al 2014; Sillmann et al, 2015).2 According to Huttunen et al. (2014), hopes connected to geoengineering as well as various major concerns and action proposals have recently been reflected in over 100 official policy documents globally. Several geoengineering options were also treated in the Intergovernmental Panel on Climate Change (IPCC)'s Fifth Assessment Report, which surprised or even provoked some observers (e.g. Petersen, 2014; Stilgoe, 2013).

Despite geoengineering's controversial potential, public geoengineering debate in the daily press from 2006 to 2013 was, according to Anshelm and Hansson (2014a, 2014b), heavily dominated by accounts of scientists' arguments for more geoengineering research or even deployment; only about $8 \%$ of mass media articles expressing outright criticism of geoengineering, with a relative over-representation of German articles (which only constituted $2 \%$ of the entire sample).3 According to Buck's (2012) review of English-language mass media articles, primarily published between 2006 and mid-2010, public statements about geoengineering were dominated by what Kintisch (2010) called the 'geoclique', i.e. a small network of scientists working on geoengineering, or by other natural scientists and engineers. Consequently, Buck (2012) found that only $2 \%$ of statements about geoengineering were made by critics. This is in line with Huttunen et al.'s (2014) finding that $65-70 \%$ of the reviewed policy documents, published up to 2013 in the USA and UK, favoured geoengineering, i.e. in various degrees accepting further research and in a few cases even deployment.

According to Harnisch et al. (2015), emergency framings and the often invoked 'Plan B' concept dominated the mass media, scientific and political contexts in the USA in 2006-2011, in the UK after the publication of the Royal Society's geoengineering report in 2009, and in Germany, although debate in Germany was much more sceptical, emphasising both ethical concerns and environmental risks and less emphasis on emergency framings and need for geoengineering research.4 Porter and Hulme (2012) claim that the mass media frames mirror current scholarly frameworks, such as that of the UK's Royal Society report, which are conveyed in a favourable tone and emphasise issues of efficiency and optimisation, embedding geoengineering in the context of progressive and reliable scientific process (which Porter and Hulme call an 'innovation frame'). According to Harnisch et al. (2015: 68), the emergency and 'Plan B' framings were also picked up in several influential political contexts, for example, in the UK government, emphasising the 'need for research'. Contrary to the present findings, Harnisch et al. (2015) propose that, considering the lack of counterarguments to the emergency framing and the related idea of geoengineering as 'Plan B', these framings could become increasingly central to geoengineering debates. However, there is also an obvious tension in this frame: on one hand, geoengineering is placed within an ecological modern (see also Buck, 2012) and traditional positivist frame and, on the other, within a narrative of technological pessimism (Porter and Hulme, 2012).

A common point of departure in the mass media articles analysed by Anshelm and Hansson (2014a, 2014b) was the depiction of climate change as catastrophic, leading to two alternatives: because of the failure of political negotiations regarding climate change, the options were either passively waiting for disaster or developing alternatives previously considered 'bizarre', 'foolish' or 'taboo', i.e. grand-scale geoengineering. This finding is in line with a master argument identified by Nehrlich and Jaspal (2012:141) in reviewing mass media articles up to 2011: 'The earth is seriously/catastrophically broken/ill and can only be fixed/healed by geoengineering'. Although the advocates of geoengineering deployment or research emphasise the risks of doing so, the option is nevertheless promoted as 'Plan B' because conventional mitigation measures may fail, given the impending climate catastrophe. Consequently, the devastating consequences of climate change can constitute a rhetorical resource in the debate: the more alarmingly the situation is depicted, the greater the claimed need for extreme measures (Anshelm and Hansson, 2014a, 2014b; Rayner, 2014).

In 2006-2013, several leading researchers in the field expressed epistemological humility, openly affirming in public debate in the mass media the inadequacy of our present and projected future knowledge of geoengineering. However, this uncertainty was seldom cited as a rejection of deployment of these technologies but rather as a main argument for more research into and assessment of geoengineering, although it was frequently acknowledged that geoengineering could have severe or even catastrophic negative side-effects. Geoengineering's theoretical potential to save the planet seemed to trump all these concerns (Anshelm and Hansson, 2014a, 2014b). Through 2014 and up to spring 2015, however, this invocation of emergency to justify geoengineering seems to be fading. 


\section{Data and analysis: Discourse in the media debate in 2014 and 2015}

Buck (2012) analysed major newspapers in English and found that, until mid-2010, mass media debate on geoengineering was dominated by natural scientists and engineers, who were cited in $70 \%$ of articles, and that only five scientists, led by Ken Caldeira and David Keith, contributed to nearly one-fourth of the articles. As Keith himself has pointed out, the time when a small group of scientific experts could dominate the debate has come to an end,5 and the debate is 'opening up', as Scholte et al. (2013) would put it. The debate is still informed by scientists, but the journalists seem to interpret and frame what the scientists are saying more critically. The concept has also found its way into popular culture with dystopian connotations, for example, in the videogame 'Civilization: Beyond Earth' and the movie Snowpiercer.6 The dominance of natural scientific perspectives seems recently to have been broken even in the scientific realm and, according to Linnér and Wibeck (2015), social science journal papers on geoengineering outnumbered natural science papers in 2013.

Recently, many scientists seem to have become more anxious to emphasise that they are reluctant advocates of a 'terrifying thing'.7 Symptomatically, Caldeira stresses that his advocacy of geoengineering research does not at all imply that he favours its deployment; on the contrary, he now stresses that he is an expert on something that he really dislikes and that it would be crazy to deploy it.8 The previous visions of the great possibilities offered by geoengineering only rarely appeared in media reporting in 2014 and 2015.9

In early 2014, Al Gore declared that the idea of large-scale intentional manipulation of the global climate to counteract global warming was 'insane, utterly mad and delusional in the extreme'.10 This view was also echoed in a few opinion pieces describing geoengineering as 'nuts', 'mad' or 'insane'.11 A similar interpretation depicted geoengineering as a 'depressing' or 'frustrating' reaction to the consequences of dysfunctional behavioural patterns and ecologically unsustainable socioeconomic structures.12 Various geoengineering technologies are now also described as 'touchy', 'highly controversial' and 'aggressive',13 whereas, unlike sulphate injection, for example, other technologies, such as bioenergy with carbon dioxide capture and storage (BECCS), are identified as 'soft'.14

Both press reports and the many quotations of German, American and Canadian researchers cited in the media describe geoengineering as a simplistic techno-fix, and the overarching message is usually that geoengineering is a non-solution that must be rejected - a message often explicitly supported by references to various reports and studies. Scientific studies are reported in the mass media to support the contention that the effects of geoengineering deployment may be dangerous, unforeseeable and uncontrollable, and that there are enormous risks that the climate effects of geoengineering will differ greatly between parts of the world, countries in the Global South disproportionately suffering from such unequal impacts. For those reasons, an article in Nature Communication that received considerable attention claimed that geoengineering cannot solve the problem of climate change, as each main geoengineering option either reduces the temperature increase by $8 \%$ at most or has potentially severe side-effects and cannot be stopped without causing rapid climate change (Keller et al., 2014). These problems and other sceptical positions have circulated in the scientific community for several years, but there has not until recently been a general reframing of mass media coverage towards emphasising these risks. 15

Another illustration of the change in mass media reporting is the sudden attention paid to Dr Matt Watson's assertion that the deployment of solar radiation management (SRM) is frightening. Watson, project leader of the British SPICE programme and co-author of the Royal Society's report, and his colleagues had been expressing similar opinions for five years, but it was not until late autumn 2014 that the mass media started to include such critical statements in news headlines, emphasising these 'confessions' as if something new had emerged. Watson's support of substantial research into geoengineering, despite his fears, received less attention than did the sensational 'confession' that actually did not deviate substantially from his statements back in 2009.16

This framing is also reflected in how the Climate Intervention reports of the National Research Council (NRC, 2015a, 2015b) in the USA were received in early 2015. Despite the resemblance of the NRC's main message to the Royal Society's 2009 analysis and recommendations, mass media interpretations and framings of the reports from 2009 and early 2015 differ significantly. While the mass media presented geoengineering as an alternative solution, or 'Plan B', in 2009, its framing in 2015 instead emphasises that neither carbon dioxide removal (CDR) nor SRM constitutes an actual solution, and that $\mathrm{CO}_{2}$ emission reductions are the only solution. Media coverage in early 2015 stresses serious warnings regarding the risks, drawbacks and side-effects of geoengineering and that these options are associated with various ethical, geopolitical, ecological, managerial, social and epistemological problems that make them 'poor alternatives'. Although the expert panel cited in the NRC reports advises increased research, geoengineering is not framed as a substitute for the more conventional options. On the contrary, the Climate Intervention reports maintain that no faith should be placed in geoengineering as a 'Plan B' or solution. The NRC expert panel's words that deployment would be 
'irresponsible' and 'irrational' have been widely quoted, and newspaper headlines keep asking whether geoengineering is 'a bad idea' and sometimes even conclude that it really is.17 On top of this, several newspapers have emphasised that these new technologies are contested or 'hugely controversial' in an entirely new way.18 The negative framing of the NRC panel's main message is not exclusive to the mass media, but can also be found in the headlines of journals such as Nature, Scientific American and New Scientist (e.g. Sillmann et al., 2015). A common position is that negative $\mathrm{CO}_{2}$ emissions, and especially BECCS, are required in order to limit global warming below $2^{\circ} \mathrm{C}$, while also emphasising major uncertainties regarding implementing these technologies, and that conventional mitigation should be the main option (e.g. Gasser et al., 2015).

Furthermore, a recurring argument is that the geoengineering concept is misleading because it bundles together several disparate technologies. The Climate Intervention reports clearly distinguish between CDR and SRM by treating them in two different reports, emphasising that 'climate intervention' is a better term than 'geoengineering'. The argument rests on the notion that an object of engineering should be a clearly demarcated or contained system that permits control, precise manipulation, systematic testing and evaluation. The geoengineering concept implies that it would also be possible to exert such control over global ecosystems and the atmosphere; as that is not the case, the reports suggest using the term 'climate intervention' instead - a term the mass media has adopted to some extent. This stresses the uncertainties, risks and uncontrollability of the approach, and the idea of planetary 'engineering' is frequently dismissed in mass media reporting.19

There is little opposition to this sceptical understanding of geoengineering and little questioning of the sceptical conclusions articulated in the articles studied. Interestingly, considering that experts tend to express overoptimism concerning the future of any technology they are engaged in developing (Tichy, 2004), not even the scientists who had previously been framed as advocating geoengineering as 'Plan B' - i.e. the 'geoclique' have defended geoengineering from this criticism. Some of them, such as David Keith, have responded to the Climate Intervention reports, stressing the need for further research.20 Others, such as John Shepherd, Chair of the Royal Society's 2009 study, welcome the recommendations of the NRC reports, stating that 'the message is just the same' as the Royal Society's but articulated differently, not mentioning that the 'Plan B' argument stressed in 2009 has weaker validity.21 Few now publicly question the position that geoengineering ought not be understood as a substitute for emissions reductions or an emergency option, and accordingly does not constitute 'Plan B'. Few actors seem to oppose the mass media's mainly negative interpretation of the Climate Intervention reports' treatment of CDR and SRM. Instead, Simon Nicholson of the American University of Washington states that 'the idea advanced by the Royal Society that albedo modification is some kind of 'Plan B' has largely fallen out of favour',22 and Metro journalist Oliver Wheaton dramatically declares that this 'bonkers plan has been smacked down in two reports by the National Academies of Science',23 illustrating more common current positions.

\section{Conclusions}

It has been suggested that as the mass media coverage of an issue expands, it generally focuses increasingly on controversy, not necessarily just on the negative aspects, but on addressing both the risks and benefits of the issue. Scholte et al. (2013) claim that this opening up of debate, a process that enables society's critical engagement, has characterised the geoengineering debate in the mass media since 2009. However, we claim that the geoengineering debate also has some unusual characteristics. As early as 2006, initial expectations were accompanied by considerable reservations, but were overshadowed by claims that geoengineering might save humanity from having to confront radical climate change (Anshelm and Hansson, 2014a, 2014b).

Interestingly, the ongoing lowering of expectations does not seem primarily attributable to the disappointment (in the technology), failed deployment or dramatic real-world events that Ungar (1992) claims are usually associated with the rise and decline of social problems, or to critical societal engagement (cf. Anshelm and Galis, 2011), but rather to a reframing in the mass media of scientific results and statements that reaffirm scientific claims that have already been made for several years.

One might claim that the shift identified here is the product of a certain mass media logic. Mass media 'hyped' geoengineering when the concept could still be described as a sensational novelty, and the claims of advocating scientists are usually prioritised when media attention is increasing (Ungar, 1992). When the notion and constituent technologies had become familiar, it was time to instead highlight their weaknesses, which many scientists had mentioned from the beginning in 2006. Such an explanation suggests that the scientific debate has been more or less stable. However, although the gradual change in mass media reporting may seem trivial, it certainly reflects some significant assumptions or trends concerning geoengineering's future prospects, 
especially if the reporting mirrors the scientific geoengineering discussions, as Harnisch et al. (2015) and Porter and Hulme (2012) claimed was the case a few years ago.

The aspirations for grand-scale control of the climate seem to have been abandoned in the mass media debate fewer than ten years after Crutzen's call in Climatic Change. Yet, the observation of the inclusion of the CDR option BECCS in the IPCC's fifth assessment reports, and its importance for reaching desirable stabilisation targets, may on the contrary be viewed as an argument for an increased importance of geoengineering, especially within scientific contexts. However, many actors consider CDR as primarily an extension of existing land management practices (Climate Geoengineering Governance 2015), or claim that BECCS shows greater resemblances to mitigation and consequently argue for not labelling this option as geoengineering (e.g. Deich, 2015). Anyhow, even a massive global CDR deployment of 5-25 GtC/yr between the years 2050 and 2150 cannot, according to e.g. Mathesius et al.'s (2015) modelling reverse the major negative impacts on the marine environment of business-as-usual $\mathrm{CO}_{2}$ emissions. In line with other influential reports from e.g. the IPCC and NRC they maintain that a massive CDR deployment have a much more negative impact on the marine environment than immediate and very substantial reductions of $\mathrm{CO}_{2}$ emissions.

Considering these results CDR is arguably not an adequate 'Plan B'. Where, then, is geoengineering heading in the absence of global intentions when both the 'geo' and 'engineering' aspects of the concept are increasingly contested and the options framed as most viable, such as BECCS, may end up being not defined as geoengineering? A Plan B is supposed to be a workable substitute for Plan A, but framing geoengineering as merely an intervention in the climate, or a minor complement to Plan A, and not a global-scale engineering effort seems to be ascribing it a fairly modest role. What is left if it is no longer considered 'Plan B'? Will an abandonment of the 'Plan B' framing and the increased ambiguity regarding the 'geoengineering' concept also be reflected in new policy documents in coming years, consequently having a fundamental influence on the future plans for these ideas?

The German case may provide some useful insights. The de-emphasis of emergency framings and emphasis of contra-arguments characterising the geoengineering debate in Germany for several years were cited as arguments for geoengineering research, but explicitly not for deployment: research is needed so Germany can be prepared to assess the risks in case other countries develop geoengineering interventions according to Harnisch et al. (2015). Such an approach, resting on a Soterian rhetoric viewing planetary control as hubris and in favour of cautiousness (Hamilton, 2013), suggests that research into geoengineering can continue even though the main arguments for its deployment are dismissed and the very concept is disintegrating. Somewhat contradictory a Soterian worldview - may dominate the coming years of political debates on technologies for controlling the global climate.

\section{Funding}

This research was funded by The Swedish Research Council Formas, grant no. 2012-1838 and 2012-725.

\section{Notes}

1. In Anshelm and Hansson (2014a, 2014b) we explain how the discourse analysis was conducted. The five languages were chosen because they are the only ones we command; $3 \%$ of the articles were in the Nordic languages, $7 \%$ in German and $90 \%$ in English.

2. See Asayama (2015) for an extended discussion on geoengineering as Plan B, an emergency and catastrophism.

3. Based on a review of 1500 mass media articles published in English, German, Swedish, Norwegian and Danish between 2006 and 2013.

4. See Harnisch et al. (2015) for an analysis of variance in national discourses (USA/UK/Germany).

5. Bill Gates backs climate scientists lobbying for large-scale geoengineering. The Guardian, 7 February 2014.

6. Taking Sid Meier's 'Civilization' Beyond Earth. Yahoo! UK and Ireland, 30 July 2014; Snowpiercer: Ambitious, Eye-Popping Post-Apocalyptic CliFi Movie Descends. Silobreaker, 8 July, 2014.

7. Can technological advances help acidifying seas? Miami Herald, 5 February 2014; Bill Gates backs climate scientists lobbying for large-scale geoengineering. The Guardian, 7 February 2014; The climate scientist who pioneered geoengineering fears it's about to blow up. Motherboard Magazine, 25 August 2014; Geoengineering creeps from sci-fi to reality. Responding to Climate Change, 21 August 2014; Geo-engineering dilemma. Times of Malta, 4 August 2014; Artificial cooling tricky topic for climate panel. Yahoo UK, 10 April 2014; Leaked IPCC climate plan to worsen global warming - ecologists. The Guardian, 7 July 2014; 'It's only a matter of time': Scientists consider geoengineering a cooler planet. 
Motherboard Magazine, 20 August 2014.

8. Bill Gates backs climate scientists lobbying for large-scale geoengineering. The Guardian, 7 February

2014; The climate scientist who pioneered geoengineering fears it's about to blow up. Motherboard

Magazine, 25 August 2014; We could stop global warming with this fix - but it's probably a terrible idea. Mother Jones, 27 March 2015.

9. For example, The climate scientist who pioneered geoengineering fears it's about to blow up.

Motherboard Magazine, 25 August 2014; Geoengineering creeps from sci-fi to reality. Responding to

Climate Change, 21 August 2014; Geo-engineering dilemma. Times of Malta, 4 August 2014; Leaked

IPCC climate plan to worsen global warming - ecologists. The Guardian, 7 July 2014; Climate change:

Geoengineering controversial, but could offer fix. $C B C, 29$ March 2014; The Planet Hacking Rules.

Atlantic Monthly, 22 August 2014; 'It's only a matter of time': Scientists consider geoengineering a

cooler planet. Motherboard Magazine, 20 August 2014.

10. Climate change: Geoengineering controversial, but could offer fix. $C B C, 29$ March 2014; Al Gore:

Geoengineering to ward off climate change is 'insane'. The Hill, 16 January 2014; Al Gore: Use of geoengineering to head off climate disaster is insane. The Guardian, 16 January 2014.

11. UN climate panel ponders Plan B, geoengineering, considered mad science by opponents. The Japan

Times, 11 April 2014; 5 insane geoengineering ideas that won't save the planet - Just make things worse.

Fast Company, 7 April 2014; 7 reasons America will fail on climate change. Vox, 5 June 2014; Can the weather be hacked to cool the planet? NO, obviously, confirm. Metro, 11 February 2015; Some climate engineering ideas are insane. This one isn't. Slate Magazine, 24 February 2015; Climate hacking is barking mad. Slate Magazine, 10 February 2015; Rethinking the unthinkable. The Guardian, 11 February

2015; Can the weather be hacked to cool the planet? Metro, 11 February 2015.

12. The white beaches of the Bahamas might come from a surprising place: Saharan dust storms. New Statesman, 29 July 2014; Climate change and geotherapy: Two conferences, two workshops, and another chance. Daily Kos, 27 July 2014. cf. Hopium is no help San Francisco Bay Area. Independent Media Center, 17 September 2014; Take steps to improve planet. St. George Spectrum, 23 September 2014. 13. Bill Gates backs climate scientists lobbying for large-scale geoengineering. The Guardian, 7 February 2014; 'It's only a matter of time': Scientists consider geoengineering a cooler planet. Motherboard Magazine, 20 August 2014; Olson gives Spoerl Lecture on geoengineering, climate change solutions. Individual.com, 8 February 2014; Community discussion: Where will geoengineering take us? Salon. com, 6 June 2014.

14. Ice911: Buying time for green innovation. Business Green, 24 January 2014.

15. Injusticia climática y geoingeniería. Rebelion, 19 April 2014; Experten sehen Climate Engineering Critisch. Deutscher Bundestag, 24 September 2014; Geoengineering plan could have 'unintended' side effect. $B B C, 8$ January 2014; Geoengineering could bring severe drought to the tropics, research shows. The Guardian, 8 January 2014; Plan to cool planet could be disastrous. New Zealand Herald, 8 January 2014; 'We can't trust capitalism to just fix this' global warming mess. Mother Jones, 23 January 2014; Why a meteorologist took the bus for 28 hours instead of flying. Slate Magazine, 4 February 2014; Olson gives Spoerl Lecture on geoengineering, climate change solutions. Individual.com, 8 February 2014; Geoengineering could actually double rate of global warming. Click Green, 18 February 2014; Renewable power tops climate change solutions in expert survey. Spectrum Online, 19 February 2014; Forslag til løsninger på global opvarming kan skabe højere temperature. U-landsnyt.dk, 19 February 2014; Climate: Geo-engineering no Holy Grail - study. AFP, 25 February 2014; Das Klima ist nicht mehr zu retten. Hannoversche Allgemeine Zeitung, 25 February 2014; Geoengineering side effects could be potentially disastrous, research shows. The Guardian, 25 February 2014; Forscher: Manipulationen am Weltklima wenig effizient und gefährlich. Weser Kurier, 25 February 2014; Geoengineering ineffective against climate change, could make worse. Yahoo UK, 26 February 2014; Erderwärmung mit technischen Eingriffen kaum zu senken. Hamburger Abendblatt, 26 February 2014; Climate engineering: Vorbeugen besser als nachträglich herumdoktern. Der Standard, 26 February 2014; Study reveals geo-engineering is not an easy way to stop climate change. The China Post, 26 February 2014; Geoengineering could have 'catastrophic consequences': Schemes to control. Daily Mail, 27 February 2014; UC Davis experts weigh in on global warming. Individual.com, 27 February 2014; Climate technofixes 'will not work'. Eco-Business, 10 March 2014; Climate engineering: Minor potential, major side effects. Pollution Online, 10 March 2014; Geoengineering is not a solution for climate change anymore. Huffington Post Canada, 10 March 2014; Iron fertilization might be ineffective against global warming, fossil study shows. Huffington Post, 21 March 2014; Giant space mirrors, cloud-seeding not practical solutions to climate change: SFU researcher. Metro Canada, 4 June 2014; There is no last-minute scientific solution to fix climate change: study. Huffington Post Canada, 5 June 2014; Cutting emissions is 'perfect option'. Eco-Business, 9 June 2014; Extreme climate engineering strategies will not work. Individual.com, 6 July 2014.

16. Scientist terrified of own tech. Yahoo UK, 26 November 2014; Are we playing God with Earth? Scientist admits he is 'terrified' of the technology developed to stop global warming. Daily Mail, 26 November 2014; Leading Bristol scientist fears own climate change technology as we could face planetary change. Western Daily Press, 26 November 2014. Controversial plan to slow global warming 'terrifies' scientist who created it. UK International Business Times, 27 November 2014; Weltraumspiegel, Algendüngen, künstliche Wolken - Er will die Erde ins Eisfach stecken: Forscher gibt eigener Idee zu. Focus Online, 1 December 2014; Geoengineering solutions to climate change must go hand in hand with cutting emissions. Cambridge News, 4 December 2014; It takes TEN years for $\mathrm{CO}_{2}$ to damage the climate. Daily 
Mail, 3 December 2014; Climate tinkers trash out a plan. Nature, 2 December 2014; Reflecting sunlight into space has terrifying consequences, say scientists. The Guardian, 11 December 2014.

17. Report: Don't try to block the Sun to fix climate change. National Journal, 10 February 2015; Scientists are pretty terrified about these last-minute fixes to global warming. Mother Jones, 10 February 2015; Climate hacking is barking mad. Slate Magazine, 10 February 2015; Geoengineering should not be used as a climate fix yet, says US science. The Guardian, 10 February 2015; No shortcut for stopping climate change, federal report finds. The Hill, 10 February 2015; Don't block the Sun to cope with global warming. Scientific American, 10 February 2015; Climate geoengineering schemes come under fire. Nature, 10 February 2015; Geoengineering is no replacement for carbon emission cuts, study warns. Click Green, 11 February 2015; Rethinking the unthinkable. The Guardian, 11 February 2015; Can 'climate intervention' help fend off global warming? Christian Science Monitor, 11 February 2015; Geoengineering debate causes storm as climate change arguments heat up. Silicon Republic, 11 February 2015; Geoengineering would be 'irrational and irresponsible'. New Scientist, 11 February 2015; Is geoengineering a bad idea? The Guardian, 11 February 2015; Geoengineering is 'irrational and irresponsible' - but should be studied. Daily Mail, 11 February 2015; Hacking the climate instead of reducing emissions is 'irrational and irresponsible', report finds. New Statesman, 12 February 2015; What's the matter with dystopia? Huffington Post, 25 February 2015; Geoengineering solutions full of hot air, experts warn. Individal.com, 18 February 2015; Bericht zum 'climate engineering': Fachleute warnen vor überstürzten Eingriffen in die Atmosphäre. Neue Zürcher Zeitung, 26 February 2015; Are ideas to cool the planet realistic? BBC, 15 February 2013; The Australian Academy of Science says man-made climate change is real. Business Insider Australia, 15 February 2015; Climate change: Trees to the rescue. News24, 16 February 2015; Geoengineering won't help people who are stuck with dirty air. Grist Magazine, 11 March 2015; Why we should talk about geoengineering even if we never do it? Grist Magazine, 17 February 2015. Why we should talk about geoengineering even if we never do it. Grist Magazine, 17 March 2015; Geoengineering won't help people who are stuck with dirty air. Grist Magazine, 11 March 2015.

18. Stealing your thunder: why geoengineering is one of science's most. London Evening Standard, 19 February 2015; Geoengineering debate causes storm as climate change arguments heat up. Silicon Republic, 11 February 2015; Rethinking the unthinkable. The Guardian, 11 February 2015; Controversial method of addressing climate change needs more study, experts say. Huffington Post, 11 February 2015; Climate hacking is barking mad. Slate Magazine, 10 February 2015; Scientists are pretty terrified about these last-minute fixes to global warming. Mother Jones, 10 February 2015; Scientific pros weigh the cons of messing with Earth's thermostat. NPR, 10 February 2015; Manipulating the climate: The case for a Plan B. USA Today, 14 February 2015.

19. Geoengineering is no replacement for carbon emission cuts, study warns. Click Green, 11 February 2015; Don't block the Sun to cope with global warming. Scientific American, 10 February 2015; Climate geoengineering schemes come under fire. Nature, 10 February 2015; Rethinking the unthinkable. The Guardian, 11 February 2015; Can 'climate intervention' help fend off global warming? Christian Science Monitor, 11 February 2015; New report sheds light on dos and don'ts of geoengineering. Mashable, 11 February 2015; National Academy: There's a good and a bad way to 'geoengineer' the planet. National Geographic, 10 February 2015; Is geoengineering a bad idea? The Guardian, 11 February 2014; Hacking the climate instead of reducing emissions is 'irrational and irresponsible' reports finds. New Statesman, 12 February 2015; Geoengineering is 'irrational and irresponsible', but should be studied anyway, says US government report. Daily Mail, 11 February 2015.

20. Give geoengineering a chance to fix climate change. $C B C, 11$ February 2015; Scientific pros and cons of messing with Earth's thermostat. NPR, 10 February 2015.

21. Geoengineering would be 'irrational and irresponsible'. New Scientist, 11 February 2015.

22. Geoengineering would be 'irrational and irresponsible'. New Scientist, 11 February 2015; Geoengineering debate causes storm as climate change arguments heat up. Silicon Republic, 11 February 2015.

23. Can the weather be hacked to cool the planet? NO, obviously, confirm scientists. Metro, 11 February 2015. See also: Geoengineering won't solve climate change: Our view. USA Today, 16 February 2015; Blocking out the Sun not the best way to fight climate change ... Yet. Forbes, 11 February 2015; Geoengineering would be 'irrational and irresponsible. New Scientist, 11 February 2015.

\section{References}

Anshelm J and Galis V (2011) (Re-)constructing nuclear waste management in Sweden: The involvement of concerned groups. In: Kumar S (ed.) Integrated Waste Management, Volume II. Rijeka: In Tech, pp. 401-430.

Anshelm J and Hansson A (2014a) The last chance to save the planet? An analysis of the geoengineering advocacy discourse in the public debate. Environmental Humanities 5: 101-123.

Anshelm J and Hansson A (2014b) Battling Promethean dreams and Trojan horses: Revealing the critical discourses of geoengineering. Energy Research and Social Science 2: 135-144.

Asayama S (2015) Catastrophism toward 'opening up' or 'closing down'? Going beyond the apocalyptic future and geoengineering. Current Sociology 63: 89-93.

Buck HJ (2012) Climate engineering: Spectacle, tragedy or solution? A content analysis of news media 
framing. In: Methmann C, Rothe C and Stephan B (eds) Interpretive Approaches to Global Climate Governance. Deconstructing the Greenhouse. New York: Routledge (Interventions), pp. 166-181.

Climate Geoengineering Governance (2015) Is there a place for geoengineering in addressing climate change? Geoengineering Governance Research. Briefing Note 7. University of Oxford.

Deich N (2015) Open letter to Fim Flannery in response to 'A “third way" to fight climate change'. Center for Carbon Dioxide Removal. University of California. Available at: http://www.centerforcarbonremoval. org/blog/2015/7/28/open-letter-to-tim-flannery-in-response-to-a-third-way-to-fight-climate-change (accessed 20 August 2015).

Gasser T, Guivarch C, Tachiiri K, Jones CD and Ciais P (2015) Negative emissions physically needed to keep global warming below $2{ }^{\circ} \mathrm{C}$. Nature Communications 6: 1-7.

Hamilton C (2013) Earthmasters: The Dawn of the Age of Climate Engineering. NewHaven and London: Yale University Press.

Harnisch S, Uther S and Boettcher M (2015) From 'go slow' to 'gung ho'? Climate engineering discourses in the UK, the US, and Germany. Global Environmental Politics 15: 57-78.

Horton JB (2015) The emergency framing of solar geoengineering: Time for a different approach. 'Perspectives and controversies'. The Anthropocene Review 2: 147-151.

Huttunen S, Skytén E and Hildén M (2014) Emerging policy perspectives on geoengineering: An international comparison. The Anthropocene Review 2: 14-32.

Keller DP, Feng EY and Oschilles A (2014) Potential climate engineering effectiveness and side effects during a high carbon dioxide-emission scenario. Nature Communications 5: 3304

Kintisch E (2010) Hack the Planet: Science's Best Hope - or Worst Nightmare - for Averting Climate Catastrophe. Hoboken: John Wiley \& Sons Inc.

Linnér B-O and Wibeck V (2015) Dual high-stake emerging technologies: A review of the climate engineering research literature. WIREs Climate Change 6: 255-268.

Loukkanen M, Huttunen S and Hildén M (2014) Geoengineering, news media and metaphors: Framing the controversial. Public Understanding of Science 23: 966-981.

Mathesius S, Hofmann M, Caldeira K et al. (2015) Long-term response of oceans to $\mathrm{CO}_{2}$ removal from the atmosphere. Nature Climate Change. Epub ahead of print 3 August 2015. DOI:10.1038/nclimate2729.

Nehrlich B and Jaspal R (2012) Metaphors we die by? Geoengineering, metaphors and the argument from catastrophe. Metaphor and Symbol 27: 131-147.

National Research Council (2015a) Climate Intervention: Carbon Dioxide Removal and Reliable Sequestration. Washington, DC: The National Academies Press.

National Research Council (2015b) Climate Intervention: Reflecting Sunlight to Cool Earth. Washington,

DC: The National Academies Press.

Petersen A (2014) The Emergence of the Geoengineering Debate Within the IPCC. Case Study, Geoengineering Our Climate Working Paper and Opinion Article Series. University College London.

Porter KE and Hulme M (2012) The emergence of the geoengineering debate in the UK print media: A frame analysis. The Geographical Journal 179: 342-355.

Rayner S (2014) To Know or Not to Know? A Note on Ignorance as a Rhetorical Resource in Geoengineering Debates. Oxford: Climate Geoengineering Governance Working Paper Series: 010.

Scholte S, Vasileiadou E and Petersen AC (2013) Opening up the societal debate on climate engineering:

How newspaper frames are changing. Journal of Integrative Environmental Sciences 1: 1-16.

Shepherd J et al. (eds) (2009) Geoengineering the Climate: Science, Governance and Uncertainty. London:

The Royal Society.

Sillmann J et al. (2015) Climate emergencies do not justify engineering the climate. Nature Climate Change 5: 290-292.

Stilgoe J (2013) Why has geoengineering been legitimised by the IPCC? The Guardian. 27 September. Tichy G (2004) The overoptimism among experts in assessment and foresight. Technological Forcasting and Social Change 71: 341-363.

Ungar S (1992) The rise and (relative) decline of global warming as a social problem. The Sociological Quarterly 33: 483-501. 